\title{
An Analysis of Educational Policies for School-aged Syrian Refugees in Turkey
}

\author{
Yusuf Alpaydın \\ Correspondence: Yusuf Alpaydın, Ataturk Education Faculty, Marmara University, Turkey. \\ Received: June 11, 2017 \\ doi:10.11114/jets.v5i9.2476 \\ Online Published: August 2, 2017 \\ URL: https://doi.org/10.11114/jets.v5i9.2476
}

\begin{abstract}
The purpose of this study is to analyse the educational policies for Syrian school-aged refugees in Turkey. In this study, we identified the policy priorities for refugees by first examining the theoretical approaches to refugee education and the common problems observed for refugee education in different countries. Using this framework, we assessed refugee students' access to education and the studies on providing quality education to school-aged refugees through an examination of the relevant legislation and research reports. This study draws attention to both the progress in this area (the development of school facilities, financial support for teachers and the provision of school supplies) and its deficiencies (the exclusion of students from outside the camps from education, staff shortages, problems preparing appropriate curricula along with special trainings and events to promote students' socio-cultural adaptation and the shortage of psycho-social support services for traumatized students).
\end{abstract}

Keywords: education policy, migration, refugee education, Syrian refugees

\section{Introduction}

Shelter-seeking refugees, having abandoned their homes because of conflict, war, or various crises, encounter a variety of difficulties when trying to settle in safe regions. Losing opportunities in their own countries while adapting to the social, cultural and economic conditions in their country of refuge is a very challenging process. Refugees are obliged to cope with various challenges and traumas, such as not knowing the legal system of their country of refuge, being denied a significant portion of their rights to citizenship, being unfamiliar with the local language, being far away from their family and social networks, being separated from family members and losing family members in conflicts. Uncertainty about the future creates severe psychological damage when peace and security are lost (Ozdogru, 2009).

Education can play a significant role in compensating for all these social, economic and cultural losses that refugees have experienced by reducing uncertainty and rebuilding a sense of confidence. Research in various disciplines has shown the benefits of education for meeting the needs of refugees (Kakkar, 2000). Moreover, refugee education in distant resettlement countries differs in terms of refugees from host countries and other countries because of several reasons such as the number of the refugees and settlement and citizenship issues (Dryden \& Peterson, 2016).

Children suffer the most severe impacts of the asylum process and comprise nearly half of the global population of refugees. The majority of these children, living under adverse conditions, do not have access to education. A global report published in 2011 by the United Nations High Commissioner for Refugees drew attention to education as the most important priority of refugee communities while noting the lack of institutional capacity to meet the educational needs of all refugees. The report indicated that refugees' access to education is generally limited across the globe, unevenly distributed from region to region and especially limited for girls and those in middle school. It also showed the relatively low quality of education: Only 6 percent of Eritrean fourth-grade refugee students in Ethiopia, for example, are thought to attain an average reading level, in many places the student-teacher ratio is 1:70 and teachers are often very poorly educated themselves. Thus, students learn very little in school. The study, which highlighted the inability of inferior education to serve a protective function, concluded that the significant institutional limitations in refugee education are due to problems with resources and coordination (UNHCR, 2014:24). Similarly, educators are responsible for recognising, reacting to and responding to the educational needs of Syrian refugees individually (Deane, 2016).

To escape the oppression of the Assad regime in Syria, Syrians started to seek refuge in neighbouring countries. About four million Syrian refugees are sheltered in neighbouring countries, according to UNHCR data. The Syrian refugee influx to Turkey began in 2011, and Turkey hosts the largest number of refugees (nearly 2,750,000 as of March 2016) is 
(Turkish Republic's Ministry of the Interior's Directorate General of Migration Management [DGMM], 2016).

The Turkish government has implemented an open-door policy towards Syrians. Syrian refugees have entered Turkey in waves, especially from parts of Northern Syria. The international protection provided to Syrians is 'provisional protection' due to the rapid massive influx straight to the Turkish border and the impossibility of implementing individual procedures for asylum (DGMM, 2015). Among their basic needs, teens' and children's education comes immediately after the necessities of shelter, nutrition and health.

\section{Method}

Scientific research is broadly categorised as causal or descriptive, depending on whether the research focuses on causal relationships or what is being researched. Descriptive models (Karasar, 2000; Buyukozturk et al. 2008) aims to describe a past or present situation as it exists. This research employs a descriptive model.

In descriptive studies, the data are obtained either by observations and surveys conducted directly by the investigator, or by integrating and interpreting previously captured records and scattered information with the investigator's observations. A significant proportion of the resources used in social science research are secondary sources (academic books and articles, statistics, reports and institutional documents created by various institutions). A key reason for using secondary sources is to enable the researcher to systematically cover as large a sample as possible and respond to research questions. The validity of the collected data is determined by its relevance to the research problem and questions. The reliability of the data is measured by the consistency of the different data on the same problem (Demirci \& Koseli, 2009).

Researchers can access the correct resources, analyse the facts in a systematic manner and answer their research questions satisfactorily in the descriptive model by being aware of their own theoretical preferences of and creating a framework for systematic analysis (Boke, 2009). Clearly specifying one's theoretical preferences in the research method is also seen as an ethical responsibility. For this purpose, we examine the main theoretical sources of refugee education in detail in the research process to develop a theoretical perspective.

The purpose of this study is to analyse policies towards the education of Syrian school-aged refugee children in Turkey. Toward this goal, we identified policy priorities towards refugee education, especially in light of theoretical approaches to refugee education, common challenges and successful applications observed in different countries. We evaluated studies the educational access and quality of education of school-aged refugees in Turkey through the legal framework related to this subject, as well as through research reports.

\section{Results}

\subsection{Theoretical Outline of Refugees' Education}

In the international literature, refugee education is considered a subtopic of education in emergencies. A prominent researcher in the theoretical and practical aspects of education in emergency situations and the crisis environment, Sinclair (2002) implied that educational planning, like educational sub-disciplines such as science education, has some distinctive characteristics despite of its commonalities with education in non-emergency situations and can also be considered a model of education for comparative training or development in emergency situations. Education in emergency situations often involves major conflicts and crises. In crises that are also at local or school level, it is necessary for interventions to consider preparing for access, resources and coordination scenarios; psychosocial support; developing a curriculum framework; developing health, safety and peripheral-topic life skills and developing civic life skills to prevent conflict (Sinclair, 2002:127). Many other researchers who have investigated schools in the context of refugee education have stated that schools that educate refugees need to be planned during times of peace, be sensitive to the issues of refugees and develop the capacity to solve problems. According to another study by Sinclair (2001), the main educational principle enabling a community-based rapid response to a crisis is training to develop teacher capabilities, youth leaders and school administrators. Education should promote durable solutions and be based on the curriculum and language of the refugees' country of origin. Education programmes should encourage the participation of underrepresented groups, such as girls, adolescents and people with disabilities and should have the flexibility to respond to the needs of newly arrived refugee children.

Changes in peoples' lives are generally slow and gradual. Refugees are in a situation in which they must cope with quite sudden and major changes. According to Bronfenbrenner's ecological theory of development, human development takes place within one's context and environment. Thus, individuals both affect and are affected by their environment. According to this theory, the real individual is defined near and far through a three-tier ecology that is broad and concerns the family. In seeking asylum, three phases reflect the processes before, during and after migration. Anderson et al. (2004), while considering the transitions experienced by refugees through motions from Bronfenbrenner's ecological theory of development, developed a theoretical framework related to the development of refugee children's education. 
Their theory primarily focuses on the factors affecting the ability to manage refugee children's transition to a new country and adaptation to a new school. This integration process differs for each refugee's transition and current situation. Relevant factors can include the degree of the trauma experienced, the family's supportiveness and the degree of the child and family's familiarity with the language and educational system of their new country. Some of the post-migration factors affecting a child's adaptation to school may be related to the child's family and relatives, the school in the community and support services. Unresolved emotional issues and trauma related to their displacement can affect children's adaptation to school and their development. The level to which a child's family adapts to their new environment will also affect the child's adaptation to a new school. Establishing a social environment familiar to children will also contribute to their school development. After migration, other variables affecting adaptation are those related to the characteristics of the school and the teachers. Because the integration process is primarily a mutual process, schools and teachers need to adapt to the children as much as the children need to adapt to the school. A school's most important feature is its willingness to change for the benefit of the children. Specifically, the school's adaptation to the needs of students, through its rules, policies, practices and teacher development, is crucial (Anderson et al., 2004).

For crisis situations of long duration, the quality of a school and the importance of learning stand out even more. In a study on the quality of refugee schools and children's level of attainment in developing countries, Williams (2001) observed that students' age, gender, health and family support were factors having a fundamental effect on student's level of attainment. Community support, teachers' qualifications, educational tools and management structure are effective for promoting students' educational attainment at a systemic level. Here in particular, the processes of teaching and learning that support a good system of evaluation are located at the centre of education. Another factor in quality and access is inclusiveness of both genders and all vulnerable groups.

Providing autonomy and flexibility to refugees is an important part of successful refugee education. A study comparing the educational models experienced by Palestinian refugees in camps in Lebanon with the model experienced by Tibetan refugees in camps in India found that while the Indian government was able to establish a supportive and autonomous educational administration, were unreserved when developing the programme and were thus able to provide education for the children, the lack of autonomy in the Palestinian camp led to unsatisfactory results. Being confined to camps for many years and being obliged to remain in the camp environment to take advantage of certain rights caused the Palestinian refugees to despair. The limitations that the Lebanese government imposed on the Palestinian refugees' continuation to secondary education and their right to work lowered the priority given to education and thus raised the high-school dropout rate (Corrigan, 2005).

Being a refugee can create opportunities for access to education in some cases. Because the crisis environment destroys traditional forms and habits to some extent, educational possibilities can become available to a wider populace, enabling formal, non-formal and informal forms of education to be developed to accommodate these new conditions (Dicum, 2005).

In conjunction with UNICEF, a study of the minimum standards of education in emergency situations developed by the Inter-agency Network for Education in Emergencies (INEE, 2010) offers the most comprehensive and orderly framework for policies, priorities and practices to be followed for refugee education. All standards were determined in workshops in which over 2,250 people from 50 different countries participated and a consensus was reached. The INEE index's last update was released in 2010 under the title INEE Minimum Standards in Education, Preparedness, Response and Recovery. These standards were developed in 2003 with the intent of developing a vehicle for identifying and measuring the minimum standards for educational access and quality in emergencies such as war and other disasters. The minimum standards are divided into five main categories: (a) foundational standards, (b) access and learning environment, (c) teaching and learning, (d) teachers and other education personnel and (e) education policy. 
Table 1. INEE Minimum Standards for Education: Preparation, Intervention and Recovery

\begin{tabular}{|c|c|c|c|}
\hline \multicolumn{4}{|c|}{ Foundational Standards } \\
\hline \multicolumn{4}{|c|}{$\begin{array}{l}\text { Community involvement in the decision and application processes related to education } \\
\text { Establishing coordination mechanisms for education } \\
\text { leeds analyses, determining strategies for educational participation and conducting regular monitoring } \\
\text { and evaluations }\end{array}$} \\
\hline $\begin{array}{l}\text { Access and Learning } \\
\text { Environment }\end{array}$ & Teaching and Learning & $\begin{array}{c}\text { Teachers and Other } \\
\text { Educational Personnel }\end{array}$ & Education Policy \\
\hline $\begin{array}{l}\text { Have access to quality } \\
\text { and affordable } \\
\text { education opportunities. } \\
\text { The learning } \\
\text { environment provides } \\
\text { psychosocial support } \\
\text { and is safe. } \\
\text { Educational facilities } \\
\text { provide for health and } \\
\text { protection. }\end{array}$ & $\begin{array}{l}\text { The curriculum used is } \\
\text { appropriate and applicable to the } \\
\text { current special situation. } \\
\text { The education staff has received } \\
\text { structured training in accordance } \\
\text { with the current needs. } \\
\text { The processes of teaching and } \\
\text { learning are learner-centred, } \\
\text { participatory and } \\
\text { comprehensive. } \\
\text { Appropriate methods are used to } \\
\text { measure and evaluate the } \\
\text { learning results. }\end{array}$ & $\begin{array}{l}\text { A sufficient number of } \\
\text { suitably qualified teachers } \\
\text { and education staff will be } \\
\text { recruited. } \\
\text { Teaching staff's work duties } \\
\text { are clear, and they receive } \\
\text { compensation for their } \\
\text { work. } \\
\text { Support and guidance } \\
\text { mechanisms act effectively } \\
\text { for education personnel. }\end{array}$ & $\begin{array}{l}\text { Education authorities, while } \\
\text { providing everyone access } \\
\text { to school free of charge, } \\
\text { give priority to the situation } \\
\text { returning to normal in the } \\
\text { shortest time. } \\
\text { Educational activities and } \\
\text { policies take into } \\
\text { consideration the relevant } \\
\text { legislation and the needs of } \\
\text { those affected by calamity. }\end{array}$ \\
\hline
\end{tabular}

Source: (INEE, 2010).

Conditions for refugees are clearly better in countries with developed social and cultural rights and a limited number of refugees. However, when students enrol in school, they face problems such as prejudice and problems integrating with children of different educational backgrounds, personal and material deficiencies, language education problems, or problems trying to learn in a multi-cultural environment while still traumatised (Bourgonje, 2010; Nonchev \& Tagarov, 2012). The same issues also stand out in two other studies on the experiences and needs of refugee children in the UK (Hek, 2005; Manyena \& Brady, 2007). Another study, which examined the experiences of asylum seekers and refugees in middle schools in England, showed that activities exemplifying inclusive policies include providing service for extra school activities to refugees outside of regular school hours, having employees act as a bridge between home and school, hiring experts to provide psychosocial support, implementing peer mentorship, offering additional courses on weekends and translating some materials into the refugee parents' language (Doyle \& McCorriston, 2008).

\subsection{School-Aged Syrian Refugees'Access to Education in Turkey}

In Turkey, approximately 15 percent of Syrian refugees reside in housing centres, while 85 percent reside outside of the housing centres (DGMM, 2016). Around 44 percent of Syrian refugees are in the 19-54 age-group, which can be considered working age, and 30 percent are primary and middle-school aged (6-18). Of the latter, a significant portion (35 percent) emanate from the areas of primary school education. With 23 percent unable to read or write, some people are only receiving literacy education (Afet ve Acil Durum Yonetimi Baskanliği [AFAD, Disaster and Emergency Management Authority], 2013: 25-27).

Syrian refugees living in Turkey have access to various educational opportunities. A dual structure is available that accommodates students in and outside of the camps. Syrian children and adolescents outside of the camp can attend private schools and Ministry of National Education (MONE) schools that accept Syrians through temporary training centres operated or supported by principalities, municipalities and NGOs. Because of limited language capability and accommodation documents, access to the Turkish schools is limited.

In the camps, however, only temporary education centres are available. While MONE has control of the educational process from preschool through the end of secondary education, the Higher Education Council (YOK, or Yuksekogretim Kurulu in Turkish) makes decisions on topics related to higher education.

The school enrollment rate in the camps is very high. In the primary and middle schools formed in camps, education is provided in Arabic by volunteer Syrian teachers following the Syrian curriculum. Those living outside the camp can continue to be educated in camp schools. At the end of each school year, students are presented with a certificate showing attendance and achievement.

Outside of the camps, however, school enrollment rates are significantly lower. Of those living outside of the camps, only those with residence permits are able to register in Turkish schools. However, the number of those going to Turkish schools is small. Syrian schools supported by NGOs are also available for those living outside of the camps (UNHCR, 2014) as 
well as private schools opened by Syrians themselves under a protocol made with MONE. However, school enrollment rates in these schools are also low because of the tuition, despite these fees being fairly low (Sonmez, 2014: 18-19). Table 2 shows the years that experienced rapid enrollment and a significant improvement in enrollment rates in 2015 .

Table 2. The number of Syrian students continuing formal education in Turkey by year (November 2015)

\begin{tabular}{lllllll}
\hline & & $\mathbf{2 0 1 1 - 2 0 1 2}$ & $\mathbf{2 0 1 2 - 2 0 1 3}$ & $\mathbf{2 0 1 3 - 2 0 1 4}$ & $\mathbf{2 0 1 4 - 2 0 1 5}$ & $\mathbf{2 0 1 5 - 2 0 1 6}$ \\
\hline Pre-school & Temporary Education Centres & 3,000 & 5,000 & 8,000 & 8,145 & 11,351 \\
& Turkish Schools & 500 & 1,000 & 2,000 & 4,911 & 3,888 \\
Primary School & Temporary Education Centres & 13,000 & 23,000 & 33,000 & 43,720 & 129,403 \\
& Turkish Schools & 4,500 & 11,500 & 40,000 & 79,255 & 46,035 \\
\multirow{3}{*}{ Middle School } & Temporary Education Centres & 7,000 & 13,000 & 20,000 & 22,595 & 56,738 \\
& Turkish Schools & 2,000 & 8,000 & 22,000 & 28,084 & 12,711 \\
Total & Temporary Education Centres & 3,000 & 4,000 & 8,000 & 10,045 & 26,036 \\
& Turkish Schools & 1,000 & 2,000 & 6,000 & 13,144 & 4,241 \\
Grand Total & Temporary Education Centres & 26,000 & 45,000 & 69,000 & 84,505 & 223,528 \\
\hline
\end{tabular}

Source: (MONE, 2014).

When hopes of a quick return faded school enrollment rates increased. In addition, the Syrian refugee community has been able to become more organised over time. In November 2015, a total of 290.000 students received education in the temporary learning centres and ministry-affiliated schools. Approximately 750.000 of the refugees were estimated to be school-aged students, meaning about 450.000 school-aged children and adolescents were not in school.

While the framework of services for foreign students in Turkey before 2010 was executed in accordance with the Foreign Students Circular (MONE, 2010), a comprehensive directive was issued to establish and develop educational services for asylum seekers because the standards in the existing circular were not being met (MONE, 2014). This circular frames social and cultural services, as well as a support framework have been identified along with opening schools for asylum seekers; buildings allocated to schools; teacher recruitment; developing the transition to higher education through student records, admissions and the equivalence process; and developing the language of education, curriculum and success evaluation.

Various activities have been conducted to support Syrian refugees' transition from secondary school to higher education. In Turkey, education certificates are provided to students in their last year of high school in the temporary education centres who have passed the graduation exam conducted by the Syrian National Coalition Provisional Government of the Ministry of Education, the Syrian Ministry of Education, or the Libyan Provisional Government of the Ministry of Education, as well as equivalency certificates, are arranged by MONE. Those who pass this exam are considered to have graduated from high school. In 2014, 5.000 Syrian students were successfully awarded certificates for these exams (AFAD, 2013). In 2015, 8.000 people registered for this exam, which was given in 14 centres (UNHCR, 2015b). Thus, Syrian students find higher education facilitated in Turkey and in other countries. Consistent with this effort, courses in Turkish language have been organised in cooperation with the Turks Abroad Department, AFAD and Turkish Learning Centres in a number of universities; students who receive the Turkish proficiency certificate in Turkey can benefit from opportunities for education, housing and scholarships.

In 2013, the Higher Education Council's (YOK) recognition of level-passage easement to all universities for Syrian students holding the certificate provided an important mechanism enabling students to transfer with the appropriate documents; students lacking these documents were able to attend courses in regional universities as special students (YOK, 2015). Because of this policy, the total number of Syrian students receiving university-level education at in 2015 reached 1,000 .

\subsection{Problems and Needs for the Education of Refugees}

When UNHCR examined Syrian refugees' objectives for education and level of attainment, they found that while progress had been made in areas such as constructing school facilities and providing school supplies, much distance remained to covered in special education and activities to make education outside the camps more inclusive for select targeted groups, for providing shuttle service to students coming from different locations and for ensuring students' social and cultural adaptation (UNHCR, 2015).

In the international literature, a study was conducted on the educational problems and needs of refugees in Jordan, Lebanon, Northern Iraq and Turkey (the countries heavily populated by refugees affected by the Syrian crisis), the previously described problems of quality due to access limitations, financial problems, education materials and teacher capacity were again found to reflect problems in coordination and cooperation along with the need for psychosocial support in these countries (Chatty et al., 2014). 
A study by Seydi (2014) evaluating Turkish policies for addressing the educational problems of Syrian refugees, noted major policy changes between the start of the Syrian crisis in 2011 and 2014. In the first years, workarounds were developed by the Turkish government with the assumption that Syrians would soon return to their own homeland. Over time, more permanent solutions began to be planned. Among the policy changes noted by Seydi's study were removing the one-year limit for university education for Syrian students, accepting transfers of those with education certificates; providing dorm and scholarship opportunities for some students; allowing the curriculum prepared by the Syrian National Coalition Higher Education Commission to be followed pending approval by MONE (which had initially been reluctant to implement a different primary and secondary school curriculum); and offering professional courses and Turkish language courses in the camps.

To improve the education of Syrian refugees, an international observer who had interviewed local officials and visited numerous schools in Turkey attended by refugee children recommended more educational services for children and adolescents outside the camps, such as programmes for conditional cash transfers primarily targeting young males to discourage child labour, a special focus on the secondary school age group to address the lower level of participation in secondary school than primary school and additional research on the population outside of the camps, along with expanded international cooperation to meet growing demands (Ackerman, 2014).

In a qualitative study of teachers working with Syrian refugees, the most important issues were people in the camps with no teacher training being recruited as teachers (especially since male teachers were leaving and seeking paying work outside of camp due to the lack of pay for teaching), incompetent management, a lack of programmes directed towards students' needs and expectations, insufficient educational tools in schools and absenteeism due to parental indifference to and anxiety about future. In addition, the negative impacts of war on children, teachers and parents significantly reduced the efficiency of education (Arabaci et al., 2014).

The majority of Syrian refugees in Turkey live outside of the camps. In a qualitative study to identify the educational and social needs of 28 educational administrators, NGO representatives and local Turkish and Syrian people in 2014 in the Kirikhan district of the province of Hatay, the prominent findings related to education were the following:

- School attendance and quality: In Kirikhan, 52 percent of school-aged children were attending school, and all of these schools were Syrian schools. The quality of education was problematic because of teachers' limited competence, lack of pay and limited support from MONE. Inadequate school facilities, overcrowded classrooms, financial needs, long distances to school, a shortage of teachers and the lack of funds for teachers' salaries were major obstacles. Another important obstacle was the requirement for a residence permit to attend Turkish schools, even if one had limited proficiency in spoken Turkish.

- Educational requirements: The requirements for accessing Syrian and Turkish schools were felt to be excessive. Eighty percent of the parents wanted to send their children to Turkish schools if possible. Syrians should learn more Turkish and should have the opportunity to attend vocational courses for immediate employment. For this reason, refugees wanted more courses to be in Turkish and English.

- Psychological support needs: The majority of Syrians felt the need for psychological support and expressed this need. Yet the number of those who could get support is quite limited (Dorman, 2014).

\section{Discussion}

Different countries share similar problems and needs that refugee-oriented education and cultural policies are trying to solve. The first of these is the right to education and access to education. Countries are grouped according to the levels of the universality and multiculturalism in their policies: The first group grants the same education rights to refugees as to citizens, the second offers differentiated access. The reason for this differentiation is also coded as legal status. In the majority of countries, authorities are reluctant to provide equal access (Nonchev \& Tagarov, 2012). In Turkey, Syrian refugees are already entitled to the same education as citizens. Refugees receive free education at every level, from preschool to tertiary education (MONE, 2014).

Another important problem area is national language education. Many researchers have referred to the importance of giving national language education to refugees. Different models of national language teaching have been used. In most countries, language education starts with introductory courses for refugee children that feed into the school programme. Another model is summer language courses in which children learn in various types of extracurricular activities with local children, interacting with their peers in an entertaining and stimulating environment. (Bourgonje, 2010; Nonchev \& Tagarov, 2012). In Turkey, Syrian refugees are given a limited amount of Turkish education in their own schools. Children who learn Turkish at a basic level are eligible for completely Turkish education in Turkish public schools. These students are provided with support trainings during off-hours.

The main problems in the training and support programmes for the refugees are the shortage of personnel to be assigned 
by the local administrations; the lack of knowledge, skills and experience in working with the refugees; and the difficulty in funding support programmes for the refugees (Manyena \& Brady, 2007). Since there is a large number of refugees in Turkey, there is no human resource problem. However, financial inefficiencies appear to be a common problem (Chatty et al., 2014).

One of the main determinants of educational qualification is teacher competence. Teachers are not trained to teach in a multi-cultural environment in their preparatory education. Moreover, teachers have limited knowledge and skills in working with traumatised children. One of the challenges faced by teachers is working with children with different educational backgrounds (Bourgonje, 2010). Despite Turkey's long history of hospitality toward refugees, teacher competencies remain a topic of debate in working with refugees in Turkey.

The majority of Syrian asylum seekers in Turkey are children and adolescents. Accessing education and receiving a quality education play a vital role in the future of refugees. However, access to education has fallen short because of the massive influx of 2.5 million people seeking refuge in Turkey. Nevertheless, supportive policies are in place to monitor the implementation of legal regulations and the recognition of refugees' rights to access to education, along with a flexible attitude that recognises and accommodates for their previous education.

Syrian refugees living in Turkey have access to various educational opportunities. However, the refugees find themselves crowded classes due to a lack of capacity. Due to language and integration issues, the number of asylum seekers that can attend the Ministry of Education schools is limited. In short, the way buildings are designed, while appearing to reflect progress on issues such as financial support for volunteer teachers and providing school supplies, remains unsuitable for providing service opportunities to future students from different places, including students outside of camp. Factors negatively impacting the quality of education are shortcomings in the qualifications of teachers and management. Teachers without work permits cannot be paid a salary, and only limited financial support is available. For this reason, male teachers in particular leave unpaid teaching to work outside the camp. In this situation, people with no teaching credentials work as teachers in the camps, and qualified managers for schools cannot be found.

School and the education process have a different meaning for refugees than they do for others. Following migration, the school ecology is of great importance for individuals' healthy development. The theory of facilitating refugee children's social and psychological adjustment and educational development highlights the importance of ensuring their current school ecology (such as the curriculum, rules and socio-cultural climate) is similar to their pre-migration ecology. When viewing refugee children and adolescents' education from this framework, the problems appear to be much greater. Several reports have drawn attention to preparing a curriculum design appropriate for the students' situation, such as special training and events targeting the selected group to ensure the students' social and cultural orientation, along with psychosocial support services for the students, most of whom have been traumatised.

\section{References}

Ackerman, X. (2014). Education for Syrian Refugees in Turkey-Beyond Camps. Brookings Institution. From<http://www.brookings.edu/blogs/education-plus-development/posts/2014/01/17-turkey-syria-refugees-educa tion-ackerman> (Retrieved May 17 2015)

AFAD, (2013). Turkiye'deki Suriyeli Siginmacilar, Saha Araştirmasi Sonuclari. Ankara: AFAD.

Anderson, A., Hamilton, R., Moore, D., Loewen, S., \& Frater-Mathieson, K. (2004). Education of refugee children: Theoretical perspectives, best practice. In: Hamilton R and Moore D (Eds.). Educational Interventions for Refugee Children: Theoretical Perspectives and Implementing Best Practice. New York: RoutledgeFalmer, 1-11.

Arabaci, İ., Basar, M., Akan, D., \& Goksoy, S. (2014). An analysis about educational problems in camps in which Syrian refugees stay: Condition analysis. International J. Soc. Sci. \& Education, 4, 668-681.

Boke, K. (2009). Sosyal Bilimlerde Arastirma. Sosyal Bilimlerde Arastirma Yontemleri. İstanbul: Alfa.

Bourgonje, P. (2010). Education for Refugee and Asylum Seeking Children in OECD Countries: Case Studies from Australia, Spain, Sweden and the United Kingdom. Belgium: Education International.

Buyukozturk, S., Cakmak, E., Akgun, O. E., Karadeniz, S., \& Demirel, F. (2008). Bilimsel Arastirma Yontemleri. Ankara: Pegem.

Chatty, D., Ahmadzadeh, H., Çorabatir, M., Hashem, L., Al Husseini, J., \& Wahby, S. (2014). Ensuring Quality Education for Young Refugees from Syria (12-25 years): A Mapping Exercise. University of Oxford: Refugee Studies Centre.

Corrigan, S. (2005). Beyond Provision: A Comparative Analysis of Two Long-Term Refugee Education Systems. Master's Thesis, Unpublished. Toronto: University of Toronto. 
Deane, S. (2016). Syria's lost generation: refugee education provision and societal security in an ongoing conflict emergency. IDS Bulletin, 47, 35-52. https://doi.org/10.19088/1968-2016.143

Demirci, S., \& Koseli, M. (2009). Ikincil Veri ve İcerik Analizi. Sosyal Bilimlerde Arastirma Yontemleri. İstanbul: Alfa.

DGMM [Turkish Republic Ministry of Interior Directorate General for Migration Management], (2015). Geçiçi Koruma. From <http://www.goc.gov.tr/icerik/gecici-koruma_409_558> (Retrieved May 21 2015)

DGMM [Turkish Republic Ministry of Interior Directorate General for Migration Management], (2016). Göç İstatistikleri-Geçici Koruma. From $<$ http://www.goc.gov.tr/icerik6/gecici-koruma_363_378_4713_icerik>(Retrieved March 15 2016)

Dicum, J. (2005). (Re) Building a feeling of belonging in complex emergencies: challenges and opportunities in the education of refugee children through the experiences of Afghans in Pakistan. Ethnologies, 27, 55-76. https://doi.org/10.7202/014022ar

Dorman, S. (2014). Educational Needs Assessment for Urban Syrian Refugees in Turkey. İstanbul: Yuva Association.

Doyle, L., \& McCorriston, M. (2008). Beyond the School Gates: Supporting Refugees and Asylum Seekers in Secondary School. London: Refugee Council.

Dryden-Peterson, S. (2016). Refugee education: the crossroads of globalization. Educ. Res., 45, 473-482.

Hek, R. (2005). The Experiences and Needs of Refugee and Asylum Seeking Children in the UK: A Literature Review. London: Department for Education and Skills.

INEE, (2010). Egitimde Asgari Standartlar; Hazirlik, Mudahale, Toparlanma. New York: Inter-Agency Network for Education in Emergencies.

Kakkar, M. (2000). Education in Places of Temporary Asylum: The Case of Afghan Refugees Living in Peshawar. Master's Thesis, Unpublished. Montreal: Concordia University.

Karasar, N. (2000). Bilimsel Arastirma Yontemi. Ankara: Nobel.

Manyena, S. B., \& Brady, E. (2007). Supporting Asylum Seeker and Refugee Children within the Education System in England. Final Report of the SPARC Project. Newcastle upon Tyne, UK: CfBT Education Trust.

MONE [Turkish Ministry of National Education], (2010). 16/08/2010 tarih ve 2010/48 Nolu Yabanci Uyruklu Öğrenciler Genelgesi.

MONE [Turkish Ministry of National Education], (2014). 23/09/2014 tarih ve 2014/21 Nolu Yabancilara Yönelik Eğitim-Öğretim Hizmetleri Genelgesi.

Nonchev, A., \& Tagarov, N. (2012). Integrating Refugee and Asylum-Seeking Children in the Educational Systems of EU Member States. Sofia: Center for the Study of Democracy.

Ozdogru, F. (2009). Dunyada multeci hareketleri, Turkiye'nin konumu ve multecilerin karsilastiklari sorunlar. In: $U$ Ozhan (Ed.) Multecilik: Sorunlar, Tanikliklar ve Cozum Yollari. İstanbul: IHH Humanitarian Relief Foundation.

Seydi, A. R. (2014). Turkiye'nin Suriyeli siginmacilarin egitim sorununun cozumune yonelik izledigi politikalar. $S D U$ Fen Edebiyat Fakultesi Sosyal Bilimler Dergisi, 31,267-305.

Sinclair, M. (2001). Education in emergencies. In: J Crisp, C Talbot and DB Cipollone (Eds.). Learning for a Future: Refugee Education in Developing Countries. Geneva: UNHCR, 1-84.

Sinclair, M. (2002). Planning Education in and after Emergencies. Paris: UNESCO.

Sonmez, Z. (2014). Komsuda Kriz: Suriyeli Multeciler. Istanbul: IHH Humanitarian Relief Foundation.

UNHCR, (2014). Sikca Sorulan Sorular Turkiye'deki Suriyeli Multeciler. From $<$ http://www.unhcr.org.tr/uploads/root/faq_-_turkish.pdf> (Retrieved May 8 2015)

UNHCR, (2015a). Syrian refugee crisis Inter-Agency Regional Update 27 April-10 May 2015. From $<$ http://www.unhcr.org.hk/files/2015\%20Emergency/Syria/May\%2015/

SyrianrefugeecrisisInter-AgencyRegionalUpdate20150510.pdf $>$ (Retrieved June 28 2015)

UNHCR, (2015b). 3RP Turkey Monthly Update-May Education. From $<$ http://data.unhcr.org/syrianrefugees/download.php?id=8972> (Retrieved June 28 2015)

UNHCR, (2015c). 3RP Turkey Monthly Update-June Education. From $<$ https://data.unhcr.org/syrianrefugees/download.php?id=9231> (Retrieved August 01 2015)

Williams, J. H. (2001). On school quality and attainment. In: J Crisp, C Talbot and DB Cipollone (Eds.). Learning for a 
Future: Refugee Education in Developing Countries. Geneva: UNHCR, 85-108.

YOK [Turkish Council of Higher Education], (2015). Suriye ve Misir Ulkelerinden Yurdumuzda Bulunan Yuksekogretim Kurumlarina Yatay Grom $<$ http://yok.gov.tr/web/guest/anasayfa/asset_publisher/64ZMbZPZISI4/content/suriye-ve-misir-ulkelerinden-yurdu muzda-bulunan-yuksekogretim-kurumlarina-yatay-gecis> (Retrieved May 20, 2015)

\section{Copyrights}

Copyright for this article is retained by the author(s), with first publication rights granted to the journal.

This is an open-access article distributed under the terms and conditions of the Creative Commons Attribution license which permits unrestricted use, distribution, and reproduction in any medium, provided the original work is properly cited. 